\title{
THE EFFECT OF CONCEPT MAPPING STRATEGY ON STUDENTS' READING COMPREHENSION AT MA ARRASYID TEMBILAHAN
}

\author{
Syafrizal \\ Islamic University of Indragiri-Tembilahan \\ E-mail: rizaltlp@gmail.com
}

\begin{abstract}
This study is aimed at finding out the effect of concept mapping strategy on the students' reading comprehension. The study was done through quasi-experimental design which involved pre-test and post-test procedures. There was a try out before administering the tests. Then,the pre-test was administered before giving treatments and the post-test was administered after the treatments. The data collection techniques were tests. The population consisted of 119 students. A cluster sampling technique was used to take them as samples. The samples were divided into two groups; experimental group and control group. Then, the data were analyzed using t-test and paired sample t-test methods to find out whether there was significant difference between the experimental group taught by using concept mapping strategy as the treatment and the control group taught conventionally. The results of the research shows that the significant probabilities were higher than $0.05(>0.05)$ ) in both paired sample t-test and independent sample t-test. It meant that there was significant difference on the students' reading comprehension in the pre-test and in the post-test of the classes. There was also a significant difference on their reading comprehension before and after treatments in the experimental class. The value of eta square was 0.68 for their reading comprehension. In sum up, the the application of concept mapping gives positive effect toward the students' reading comprehension.
\end{abstract}

Keywords: concept mapping, reading comprehension

\begin{abstract}
Abstrak
Tujuan dari penelitian ini adalah untuk mengetahui pengaruh strategi pemetaan konsep terhadap pemahaman membaca siswa di Madrasah Aliyah Arrasyid di Tembilahan. Desain penelitian ini merupakan penelitian eksperimen semu (quasiexsperiment) dengan prosedur pre-tes dan post-tes. Terdapat uji coba soal sebelum test, dan kemudian dilanjutkan dengan pre-tes sebelum perlakuan dan post-tes setelah perlakuan. Teknik pengumpulan data penelitian ini menggunakan tes. Populasi berjumlah 119 peserta didik. Penelitian ini menggunakan teknik cluster sampling untuk mendapatkan sampel yang dibagi menjadi dua kelompok; kelompok eksperimen dan kelompok kontrol. Kemudian, data dianalisis dengan menggunakan independent sample t-test dan metode paired sampel t-test untuk mengetahui apakah ada perbedaan yang signifikan antara kelompok eksperimen
\end{abstract}


yang diajar dengan menggunakan strategi pemetaan konsep sebagai perlakuan, dan kelompok kontrol yang diajarkan secara konvensional. Hasil penelitian menunjukkan bahwa probabilitas signifikan lebih tinggi dari $0,05(>0,05)$ pada paired sample t-test dan independent sample t-test, itu berarti bahwa ada perbedaan yang signifikan pada pemahaman membaca siswa kedua kelas. Dan di post-tes dari kedua kelas, ada perbedaan yang signifikan dari pemahaman membaca siswa sebelum dan sesudah perlakuan dikelas eksperimen. Nilai eta square adalah 0.68 untuk pemahaman membaca siswa. Secara singkat dapat dikatakan bahwa penerapan stategi pemetaan konsep memberikan pengaruh yang positif terhadap pemahaman membaca peserta didik.

Kata kunci: Concept Mapping, pemahaman membaca

\section{INTRODUCTION}

Most of countries around the world include English as an important subject in their school curriculum. In Indonesia, English has been taught in almost every school level. In the elementary school level, English becomes a local content subject. From the junior to senior secondary school level, it becomes a compulsory subject. And in the university level, it becomes a complementary subject. Moreover, English has been introduced to kindergarten students, with big expectation that in long span of time.

Reading is one of the most essential skills to be mastered in language learning. It is also a wonderful habit and can bring many benefits. One of the benefits of reading is a broad store of information. Moreover, reading becomes essential for everyone in order to increase his or her knowledge. This idea is supported by the fact that reading has become a part of our daily life. Therefore, being able to read is essential, especially in English, because there are many kinds of texts written in English.

Because reading is important, reading comprehension needs the technique or strategies to gain the level of reading. Brown (2001) states that strategy is a specific method of approaching a problem or task, modes of operation for achieving a particular ends, and planed designs 
or controlling and manipulating certain information. Garner (1978) states that reading strategy is an action or series of actions employed in order to construct meaning. Furthermore, technique or strategy is the one of factors that may contribute to the development of reading comprehension beside the listening comprehension, fluency and decoding. Moreover, the teacher should have suitable strategies in teaching reading to make the students comprehend more.

Many strategies are very useful in teaching reading. One of teaching reading strategies is Concept Mapping. Novak and Gowin (1984) introduced concept mapping to "facilitate the process of meaningful learning". Moreover, Concept Mapping is a graphic organizational technique designed to help individuals and groups, explain and explore their knowledge and understanding of a topic" (Hay \& Kinchin, 2006: 130). Concept maps consist of concepts, usually enclosed in circles or boxes, and relationships between concepts are indicated by a connecting line which links two concepts. Words which are written on linking lines show the relationship between two concepts. Concept is defined as "a perceived regularity in events or objects, or records of events or objects, designated by a label" (Novak \& Cañas, 2006). Concept maps are visual manifestations of students' interpretation of an idea. Students connect their previous knowledge to new information and create maps which show interrelated ideas. Moreover, concept mapping helps students find relationships among different pieces of information and build on their previous knowledge and experiences.

However, based on observation and the interview at MA Arrasyid which is located at Sungai Luar at Tembilahan regency, the fact revealed that the student's reading comprehension is still low. More students are not able to identify the main ideas, generic structure, language features, or reference. It is also hard for them to find the meaning of the vocabulary and the inference. Furthermore, when the teacher gave them some quetions the 
students could not answer it well. They did not comprehend the given text; they got nothing after their reading. Besides, the teacher still uses conventional method in teaching reading.

Hence, to comprehend the content of the text, students not only need good mastery of English, but also need an appropriate reading comprehension strategy. To control how the students learn and to help the students become more effective language learner, the teacher need an appropriate strategy.

Based on these problems, it is assumed that concept mapping strategy gives significant influence toward students' English reading comprehension. So it necessary to conduct a research entitled "the effect of concept mapping strategy on the students' reading comprehension at MA Arrasyid sungai luar tembilahan"

The major objective of this study is to find the effect of Concept Mapping strategy on students' reading comprehension at MA Arrasyid Sungai Luar Tembilahan.
The hypothesis of this study are stated below and the expected result is alternative hypothesis $(\mathrm{Ha})$ is accepted.:

Ho: There is no significant effect of Concept Mapping strategy on students' reading comprehension at MA-Al Rasyid Sungai Luar Tembilahan

Ha: There is a significant effect of Concept Mapping strategy on students' reading comprehension at MA-Al Rasyid Sungai Luar Tembilahan

\section{Nature of Reading Comprehension}

Reading comprehension is one of the skills that must be developed at schools. This is caused that the reading comprehension has become something important for students. The students" success depends on their ability to read. If students' reading comprehension is lacking, it is possible to fail in learning or at least the students will have difficulty in making progress. On the other hand if a student has an ability to 
read with proper understanding, he or she would have a better chance to succeed in learning. Presley (2012:140) states that the development of comprehension skills is a long term developmental process which depends on language and text experiences from early stage of life. Learning how to decode and learning to abstract the meanings of vocabulary words are commonly encountered in texts.

Harris (1980:3) defines reading as the meaningful interpretation of written or printed verbal symbols. This definition is also supported by Hills (2003:64) who states that reading is a fluent process of readers combining information from a text and their own background knowledge to build meaning. Maibodi (2008: 42) also states the same way that reading requires the reader to focus attention on the reading materials and integrate previously acquired knowledge and skills to comprehend what someone else has written.

Comprehension is defined as the ability to understand and get meaning from spoken and written language and is the ultimate goal in learning to read. The goal of Comprehension is to teach learners specific strategies to use for understanding text as they are reading.

$$
\text { Another idea of }
$$
comprehension is given by Coe, et al (2005:389) which state that comprehension is a complex transactional process involving the reader, the text, and the purpose for reading. The major means of focusing on comprehension of the text are typically used comprehension question. The focuses of comprehension typically cover literal comprehension of the text, drawing inferences from the text, using the text for other purposes in addition to understanding and responding critically to the text.

In brief, the reader is not only looking at texts but also presumably thinking what he is reading, what it means to him, how it relates to other things he has read, to things he knows, to what he expects to come next in texts. It means that there is an interaction between the reader and 
the text where the reader is able to read the texts and understand them.

King and Stanley (1990: 44) explain five components of reading comprehension contained in reading text which are appropriate with the senior high school curriculum. They are finding factual information, main idea, the meaning of vocabulary in context, identifying reference and making inferences. The theory above can be described as follow;

a) Finding main idea

Reading concerns with meaning to a greater extend that it is with form. An efficient reader understands not only the ideas but also their relative significance as expressed by author, in order words, some of ideas are super ordinate while other subordinate.

b) Finding factual information/ details

Factual information requires readers to scan specific details. There are many types of question of factual information such as; question type of reason, purpose, result, comparison, means, identify, time, and amount. In which most of the answer can be found in the text. c) Finding the meaning of vocabulary in context

It means that the readers could develop they guessing ability to the word which is unfamiliar with them, by relating the close meaning or unfamiliar words to the text and the topic of the text that is read. The words have the same meaning as another word.

d) Identifying references

Recognizing references words or phrases to which they refer will help readers understand the reading passage. Students of English might learn many rules for the sentences. Reference words are usually short and are frequently pronouns, such it, she, he, this, those, and so on.

e) Making inference

The importance of reading is to understand what the writer wrote; it is expected that reader can infer the writer wrote. In order words, a good reader is able to draw inference logically and make accurate prediction.

It means that factual information requires reader to scan specific detail, recognition of the main idea of a paragraph is very 
important because it helps the reader understands the paragraph and contents of reading text, when the students find the meaning of vocabulary in the context, it can develop his or her guessing ability to the word which is unfamiliar with him or her by relating the close meaning of unfamiliar words. In identifying of reference the words or phrase, the students are able to identify the word to which they refer to will help the students understand the reading passage. In making inference, it is a skill where the students are able to read between lines. It divides into main attention, draw logical inferences and make accurate predictions.

So, based on experts' opinion above, it can be inferred that reading comprehensions is one's ability in comprehending the message of the English reading materials. It is an interactive and thinking process of transferring printed letters into meaning in order to communicate certain message between the writer and the reader. It involves the process in identifying the text elements such as; finding main idea, details, the meaning of vocabulary in context, identifying reference, and making reference. Then, those become indicators for reading comprehension of this research.

\section{Concept Mapping}

Concept mapping strategy was developed at Cornell University and came to the attention of education specialists shortly after the publication of a book by Novak \& Gowin (1984) titled 'Learning How to learn'. Concept mapping is a classroom activity, which involves making of a diagrammatic representation of the relationship between the major concept (topic) and the subordinate (minor) concepts in a hierarchical order. Concept mapping was at first the investigator's construction of the concepts and propositions expressed by the learner, either in an interview or in a work sample (Novak and Gowin, 1983).

A concept map presents the relationships among a set of connected concepts and ideas. It is a tangible way to display how your 
mind "see" a particular topic. By constructing a concept map, you reflect on what you know and what you don't know. In a Concept Map, the concepts, usually represented by single words enclosed in a rectangle (box), are connected to other concept boxes by arrows. A word or brief phrase, written by the arrow, defines the relationship between the connected concepts. Major concept boxes will have lines to and from several other concept boxes generating a network. (Novak, 1998).

Concept maps facilitate the meaningful and long-life learning knowledge through presenting a pattern and a framework (Novak \& Cannas, 2006, Liaght, 2006). Concept mapping depict important concepts across a selection of text and show how they connect structurally. As a teaching strategy, students use a map developed by the teacher. As a learning strategy, students develop their own maps. In a text mapping, the major concepts of a passage attach to major branches in a diagram to which minor branches are added for details.
Branches can be labeled to represent the rhetorical structure. Chang (2008) introduces concept map as an educational technique that links new information to prior knowledge structure and introduces conceptual understanding through meaningful showing of concepts. Concept maps in various ways, creating map by learner, creating map by teacher and students and presenting the map to the learners, can be used in teaching and learning.

\section{METHOD}

The design of the research is experimental research. Experimental research is the type of research that can test hypotheses to establish cause and effect relationships (Gay and Airasian, 2000:367). The type of experimental research in this research is quasi-experimental which focuses on the non-equivalent control group. In conducting this research, two classes will be involved. One class will be experimental group and one class will be control group. The experimental class are the class that will be taught by using Concept 
Mapping. On the other hand, control class is the class which will not use Concept Mapping.

The population of this research was the first year students of MA Arrasyid, Sungai Luar Tembilahan. The total number of the population is 119 . The sampling technique was cluster sampling. The classes used in this study were selected randomly because all of the classes are homogenous. X/a was the control class and $\mathrm{X} / \mathrm{b}$ was the experimental class. In these two classes there were 26 male and 34 female students. The total numbers of the students which were taken as sample are 60.

The reading comprehension test used to gain information related to reading comprehension was in the form of multiple choice questions. The total number of item is 30 in the form of multiple choices. The pretest and post- test were administered to control group and experimental group. The data were analyzed using
SPSS (Statistical Package for the Social Sciences)

\section{FINDINGS AND DISCUSSION}

\section{Findings}

This study is an effort to find out whether there is a significant difference of students' reading comprehension after giving the treatment by using Concept Mapping strategy. If the significance value is bigger than 0.05 , this indicates that there is no violation of the assumption of equality of variance and that equal variances are assumed for the variable concerned and if the significance value is smaller than 0.05 this indicates that there is no violation of the assumption of equality of variance. Independent sample t-test and paired sample t-test were used to determine any significant effect.

\section{The classification of students' reading comprehension in experiment and control class}


Table 1. The classification of students reading comprehension pre-test score in experimental class

\begin{tabular}{|c|c|c|c|c|}
\hline No & Categories & Score & Frequency & Percentage (\%) \\
\hline 1 & Very Good & $80-100$ & 0 & 0 \\
\hline 2 & Good & $66-79$ & 6 & 19.9 \\
\hline 3 & Sufficient & $56-65$ & 17 & 56.6 \\
\hline 4 & Less & $40-55$ & 7 & 23.3 \\
\hline 5 & Fail & $30-39$ & 0 & 0 \\
\hline \multicolumn{3}{|c|}{ Total } & 30 & 100 \\
\hline
\end{tabular}

Based on the table 1, it can be seen that there were 5 categories for students reading comprehension pretest score of the experimental class. The frequency of Very Good category is 0 student $(0 \%)$, the frequency of Good category are 6 students (19.9\%), the frequency of sufficient category is 17 students $(56.6 \%)$, the frequency of Less category are 7 students (23.3\%), and there is no student categorized into Fail $(0 \%)$. The table shows that the highest percentage of student classification of students reading comprehension pre-test score of the experimental class is $56.6 \%$. Thus, the majority of the students in the experimental class before being taught by using concept mapping strategy are classified as sufficient.

Table 2. The classification of students reading comprehension post-test score in experimental class

\begin{tabular}{|c|c|c|c|c|}
\hline No & Categories & Score & Frequency & Percentage (\%) \\
\hline 1 & Very Good & $80-100$ & 4 & 13.3 \\
\hline 2 & Good & $66-79$ & 22 & 73.4 \\
\hline 3 & Sufficient & $56-65$ & 4 & 13.3 \\
\hline 4 & Less & $40-55$ & 0 & 0 \\
\hline 5 & Fail & $30-39$ & 0 & 0 \\
\hline \multicolumn{3}{|c|}{ Total } & 30 & 100 \\
\hline
\end{tabular}

Based on the table 2, it can be seen that there are 5 categories for students reading comprehension post-test score of the experimental class. The frequency of Very Good category are 4 students $(13.3 \%)$, the 
frequency of Good category are 22 students $(73.4 \%)$, the frequency of Sufficient category are 4 students (13.3\%), and there is no students in the frequency of Less category and Fail category $(0 \%)$. The table shows that the highest percentage of student classification of students reading comprehension post-test score of the experimental class is $73.4 \%$. Therefore, the majority of the students in the experimental class after being taught by using concept mapping strategy are classified as Good.

Table 3. The classification of students reading comprehension pre-test score in control class

\begin{tabular}{|c|c|c|c|c|}
\hline No & Categories & Score & Frequency & Percentage (\%) \\
\hline 1 & Very Good & $80-100$ & 0 & 0 \\
\hline 2 & Good & $66-79$ & 17 & 56.6 \\
\hline 3 & Sufficient & $56-65$ & 11 & 36.6 \\
\hline 4 & Less & $40-55$ & 2 & 6.7 \\
\hline 5 & Fail & $30-39$ & 0 & 0 \\
\hline \multicolumn{2}{|c|}{ Total } & 30 & 100 \\
\hline
\end{tabular}

Based on the table 3, it can be seen that there are 5 categories for students reading comprehension pretest score of the control class. The frequency of Very Good category is 0 students (0\%), the frequency of Good category is 17 students $(56.6 \%)$, the frequency of sufficient category is 11 students $(36.6 \%)$, the frequency of Less category is 2 students $(6.7 \%)$, and there is no student categorized into Fail $(0 \%)$. The table shows that the highest percentage of student classification of students reading comprehension pre-test score of the control class was $56.6 \%$. Thus, the majority of the students in the control class were classified as good and sufficient. 
Table 4. The classification of students reading comprehension post-test control class

\begin{tabular}{|c|c|c|c|c|}
\hline No & Categories & Score & Frequency & Percentage $(\%)$ \\
\hline 1 & Very Good & $80-100$ & 0 & 0 \\
\hline 2 & Good & $66-79$ & 16 & 53.3 \\
\hline 3 & Sufficient & $56-65$ & 14 & 46.6 \\
\hline 4 & Less & $40-55$ & 0 & 0 \\
\hline 5 & Fail & $0-39$ & 0 & 0 \\
\hline \multicolumn{3}{|c|}{ Total } & 30 & 100 \\
\hline
\end{tabular}

Based on the table 4, it can be seen that there are 5 categories for students reading comprehension post-test score of the control class. The frequency of Very Good category is no student $(0 \%)$, the frequency of Good category are 16 students $(53.3 .7 \%)$, the frequency of sufficient category is 14 students $(46.6 \%)$, and the frequency of Less and Fail category are no student $(0 \%)$. The table shows that the highest percentage of student classification of students reading comprehension post-test score of the control class was $53.3 \%$. Thus, the majority of the students in the control class after being taught by using non-concept mapping strategy are classified as Good and Sufficient.

Pre-test and post-test analysis of experimental and control class using Independent Sample T-test and Paired Sample T-test.

Table 5. The Analysis of Independent Sample T-test of Pre-test reading comprehension score between Experimental and Control

\begin{tabular}{|l|l|l|l|l|l|l|l|}
\hline Subject & Research Groups & Mean & $\begin{array}{l}\text { Standard } \\
\text { Deviation }\end{array}$ & N & df & T & $\begin{array}{l}\text { Sig.(2- } \\
\text { tailed) }\end{array}$ \\
\hline $\begin{array}{l}\text { Pre- } \\
\text { test }\end{array}$ & Experimental Group & 58.70 & 7.086 & 30 & 58 & 3.948 & .000 \\
\hline & Control Group & 66.00 & 7.235 & 30 & & & \\
\hline
\end{tabular}


Based on Independent T-test analysis for pre-test reading comprehension score of experimental and control groups on Table 5 above, it shows that there is difference at pre-test reading comprehension between experimental and control groups. T-test result is 3.948 , its df is 58, standard deviation of experimental group is 7.086 and control group was 7.235 So, in the conclusion $\mathrm{p}=.000$, the 2-tailed value was bigger than $0.05(\mathrm{p}>0.05)$. The result shows that the mean scores are different between two groups but the different is not really much. It could be determined that the subjects in both groups are a little bit different before giving the treatment.

Table 6. The Analysis of Independent Sample T-test of Post-test score between Experimental and Control Group

\begin{tabular}{|l|l|l|l|l|l|l|l|}
\hline Subject & Research Groups & Mean & $\begin{array}{l}\text { Standard } \\
\text { Deviation }\end{array}$ & N & df & T & $\begin{array}{l}\text { Sig.(2- } \\
\text { tailed) }\end{array}$ \\
\hline $\begin{array}{l}\text { Post- } \\
\text { test }\end{array}$ & Experimental Group & 73.90 & 7.471 & 30 & 58 & 4.733 & .000 \\
\hline & Control Group & 65.47 & 6.279 & 30 & & & \\
\hline
\end{tabular}

Based on Independent T-test analysis for post-test reading comprehension score of experimental and control groups on Table 6 above, it showed that there is significant difference at post-test reading skill between experimental and control groups. T-test result is 4.733 , its $d f$ was 58, standard deviation of experimental group was 7.471 and control group was 6.279 . So, in the conclusion $\mathrm{p}=0.000$, the 2-tailed value was smaller than 0.05 $(p<0.05)$. The result showed that the mean scores differ much between both groups. It could be determined that the subjects in both groups are not equivalent after giving the treatment. 
Table 7. The Analysis of Paired Sample T-test Between Pre-test and Post-test on students reading comprehension for Control Group

Paired Samples Test

\begin{tabular}{|l|c|c|c|c|c|c|c|}
\hline Subject & Group Score & Mean & $\begin{array}{c}\text { Standard } \\
\text { Deviation }\end{array}$ & N & df & T & $\begin{array}{c}\text { Sig.(2- } \\
\text { tailed) }\end{array}$ \\
\hline Reading & Pre - test Score & 66.00 & 7.235 & 30 & 29 & .277 & .784 \\
\hline & Post - test Score & 65.47 & 6.279 & 30 & & & \\
\hline
\end{tabular}

From the table 7 above, the probability $<0.05$ alternative output of paired sample test shows hypothesis $\left(\mathrm{H}_{\mathrm{a} 1}\right)$ is accepted. that the t-test result is .277 , its $\mathrm{df}$ is Because the significance is $0.784>$ 29, by comparing number of 0.05 , thus, $\mathrm{H}_{0}$ is accepted while $\mathrm{H}_{\mathrm{a}}$ is significance. If probability $>0.05$, null rejected.

hypothesis $\left(\mathrm{H}_{01}\right)$ is rejected. If

Table 8. The Analysis of Paired Sample T-test Between Pre-test and Post-test on students reading comprehension for Experimental Group

Paired Samples Test

\begin{tabular}{|l|c|c|c|c|c|c|c|}
\hline Subject & Group Score & Mean & $\begin{array}{c}\text { Standard } \\
\text { Deviation }\end{array}$ & $\mathbf{N}$ & $\mathbf{d f}$ & $\mathbf{T}$ & $\begin{array}{c}\text { Sig.(2- } \\
\text { tailed) }\end{array}$ \\
\hline Effect & Pre - test Score & 58.70 & 7.086 & 30 & $\begin{array}{c}7.95 \\
9\end{array}$ & 2 & .000 \\
\hline & Post - test Score & 73.90 & 7.471 & 30 & & & \\
\hline
\end{tabular}


From the table 8 above, the output of paired sample test shows that the t-test result is 7.952 , its $\mathrm{df}$ is 29 , by comparing number of significance. If probability $>0.05$, null hypothesis $\left(\mathrm{H}_{01}\right)$ is rejected. If probability $<0.05 \quad$ alternative hypothesis $\left(\mathrm{H}_{\mathrm{a} 1}\right)$ is accepted. Because the significance is $0.000<$ 0.05 , thus, $\mathrm{H}_{\mathrm{a}}$ is accepted while $\mathrm{H}_{0}$ is rejected.

The percentage of significant effect between pre-test and post-test of experimental class by looking for the effect size or eta-squared is $68 \%$ on the reading comprehension on narrative text. Therefore, the Ho hypothesis is rejected and $\mathrm{Ha}$ is accepted that there is a significant effect of Concept Mapping strategy on students' reading comprehension at MA-Al Rasyid Sungai Luar.

\section{Discussion}

Based on the hypothesis testing, this research proves that concept mapping strategy can increase the students' reading comprehension and their reading motivation. The students showed their enthusiasm to be engaged in learning activities and their improvement in their reading comprehension and their reading interest.

This is also in line with Shiri (2012). He said that applied research on language learning strategies indicated that semantic maps are frequently used graphic organizers that help students analyze texts and group the ideas into meaningful clusters. For instance, Kim et al. (2004) reviewed previous research studies examining the effects of graphic organizers or sometimes called concept mappping on reading comprehension. Their findings indicated that certain types of graphic organizers were more effective than others: Semantic organizers, cognitive maps were found to be highly effective in improving reading comprehension.

According to Panatda (2010) Many studies have attempted to incorporate the use of concept mapping techniques to improve learners' reading comprehension ability at different levels ranging from elementary to high school. For 
example, a study (Singtui, 2008) employed mind mapping/concept mapping techniques to develop reading comprehension skills in English for communication of Mattayomsuksa 3 students and found that there were 40 students of which $86.96 \%$ passed the prescribed criterion of $75 \%$. A study (Deesri, 2002) conducted with Mathayomasuksa 1 students discovered that the English reading comprehension post-test mean score of students who were taught by mind mapping techniques was significantly higher than those of the pre-test. The students' attitude towards the mind mapping techniques also increased. Maestas \& Croll (1985) carried out a study on the effects of training in story mapping procedures on the reading comprehension of poor readers. It was found that there was an increase on the students' ability to answer comprehension questions and increased tendency to maintain story mapping component in their story recall.

The results of the mentioned studies indicate that concept mapping strategy can help to improve students' reading comprehension ability. Furthermore, Once students acquire ConceptMapping skills, they can use it to organize and integrate information; assess existing knowledge; and gain insights into new and existing knowledge. It is an activity that provides the students with an opportunity to organize, summarize, analyze and evaluate many different ideas. It thus, promotes critical thinking skills. The process externalizes the concepts in the student's existing knowledge structure, hence, making it possible to identify misconceptions, incongruities and weaknesses in that structure.

\section{CONCLUSION}

Based on findings and discussion explained above, it can be concluded that the effect of using concept mapping strategy in teaching reading can improve students' reading comprehension significantly. 


\section{REFERENCE}

Airasian, P and L. R. Gay. (2000). Educational Research: Competencies for Analysis and Application Sixth Edition. New Jersey: Prentice Hall Inc.

Anong, Singtui. (2008). Using Mind Mapping to Develop Reading Comprehension skills in English for Communication of Mattayomsuksa 3 students. Master of Education, Curriculum and Instruction. Khongen University.

Asadollahfam, Hassan \& Shiri, Parvar (2012). The Impact of Semantic Mapping Instruction on Iranian EFL Learners' Reading Comprehension of Expository Texts. Received 18 April 2012; accepted 26 September 2012

Brown, H. (2000). Principles of language learning and teaching. New Jersey: Prentice Hall.

Brown, H.D. (1994). Teaching by Principle and Interactive Approach to language Pedagogy. San Francisco State University. Prentice Hall Regents. A Person Education company. 10 bank street. White Plains, NY 10606.

Chang Chiou- Chei (2008). The effect of concept mapping on students' learning achievements and interests.
Innovations in Education and Teaching International Vol. 45, No. 4, November 2008, 375387

Chang, K., Sung, Y., \& Chen, I. (2002). The effect of concept mapping to enhance text comprehension and summarization. The Journal of Experimental Education, 71(1), 5-23.

Gay, LR. (1987). Education Research Competence for Analysis and Application. New York: Merrill Published Ltd.

Harris, A. J. \& Sipay, E. R. (1984). How to Increase Reading Ability. Seventh Edition. New York: Longman

Hay, D., Kinchin, I., \& Lygo-Baker, S. (2008). Making learning visible: The role of concept mapping in higher education. Studies in Higher Education, 33(3), 295-311.

Hills, McGraw. (2003). Practical English Language Teaching (1st Ed.). New York. The McGraw Hill Company

Kim, A. H., Vaughn, S., Wanzek, J., \& Wei, S. (2004). Graphic Organizers and their Effects on the Reading Comprehension of Students with LD: A synthesis of Research. Journal of Learning Disabilities, 37(2), 105-118. 
Maibodi, Ashraf Haji. (2008). LearningEnglish through Short Stories. Iranian Journal of Language Studies (IJLS), Vol. 2(1).

Novak, J. D. (1998). Learning, creating, and using knowledge: Concept maps as facilitative tools for schools and corporations. Mahwah, NJ: Lawrence Erlbaum.

Novak, J. D., \& Cañas, A. J. (2008). The theory underlying concept maps and how to construct and use them. Technical Report IHMC CmapTools 2006-01 Rev 01 2008, Florida Institute for Human and Machine Cognition.

Novak, J. D., \& Gowin, D. B. (1984). Learning How to Learn. New York: Cambridge University Press.

Piyarat, Deesri. (2002). The study of English Teaching Effectiveness with Mind Mapping Technique on Reading Comprehension and English reading Attitude, Master of Education, Curriculum and Instruction. Nakornsawan Rajabhat University.
Siriphanich Panatda (2010), The 2nd International Conference on Humanities and Social Sciences April 10th, 2010 Faculty of Liberal Arts, Prince of Songkla University. 